\title{
PENDIDIKAN KEWARGANEGARAAN: MEMBANGUN MASYARAKAT DEMOKRASI YANG BERKEADABAN DARI SAAT INI
}

\author{
Bunga Bhagasasih Al-khansa \& Dinie Anggraeni Dewi \\ Universitas Pendidikan Indonesia \\ bungabhagasasih@gmail.com
}

\begin{abstract}
Abstrak
Penelitian ini bertujuan memberikan gambaran pengembangan nilai- nilai keberadaban kemanusiaan di dalam masyarakat bangsa Indonesia yang memiliki semboyan Bhineka Tunggal Ika, dan memiliki nilai Pancasila syla ke 2 yaitu "Kemanusiaan yang Adil dan Beradab", serta memiliki sumber hukum yang tertinggi yaitu Pembukaan Undang-Undang Dasar 1945. Metode penelitian menggunakan pendekatan kualitatif dengan studi kasus, berupa observasi dalam berita dan berbagai jurnal lainnya agar lebih berkembang dalam penjelasan artikel ini. Hasil penelitian menunjukkan bahwa dengan kita menanamkan nilai- nilai Pancasila dari mulai sekarang dan menjadikan manusia yang cerdas, maka masyarakat Indonesia mampu memiliki nilai-nilai keberadaban kemanusiaan. Dengan ini keberhasilan sudut pandang dari Pendidikan Kewarganegaraan akan tercapai, karena nilai-nilai keberadaban pada masyarakat demokrasi merupakan tujuan dari Pendidikan Kewarganegaraan tersendiri.
\end{abstract}

Kata kunci: Tujuan Pendidikan kewarganegaraan, masyarakat demokrasi, nilai- nilai keberadaban

\begin{abstract}
This study aims to provide an overview of the development of values of human civilization in Indonesian society which has the motto of Bhineka Tunggal Ika, and has the second Pancasila syla value, namely "Just and Civilized Humanity", and has the highest source of law, namely the Preamble of the Law. Basic 1945. The research method uses a qualitative approach with case studies, in the form of observations in news and various other journals so that it is more developed in the explanation of this article. The results of the research show that by instilling Pancasila values from now on and making intelligent humans, the Indonesian people will be able to have the values of human civilization. With this, the success of the Citizenship Education point of view will be achieved, because the values of civilization in a democratic society are the goal of Citizenship Education in itself.
\end{abstract}

Keywords: Citizenship Education Objectives, democratic society, civilized values

\section{PENDAHULUAN}

Pendidikan pada umumnya adalah proses pengubahan sikap dan tingkah laku seseorang atau sekelompok orang dalam usaha mendewasakan manusia melalui upaya pengajaran dan pelatihan. Dan menginginkan semua manusia mendapatkan kemajuan hidup yang baik secara lahir maupun batin. Dengan memberikan tuntunan di dalam hidup dan menumbuhkan jiwa raga manusia sehingga kelak dalam garis-garis kodrat pribadinya dan pengaruh segala keadaan yang mengelilingi dirinya, mampu mendapat kemajuan dalam hidupnya lahir dan batin menuju adab kemanusiaan, dan ini diperlukannya pengembangan yang baik pula, agar terwujudnya harapan dalam sebuah pendidikan tersebut.

Dalam segala sesuatu harus ada yang dikembangkan yaitu dengan cara membangun pendidikan karakter yang baik melalui pendidikan. Arti kata pengembangan berarti "proses, cara, perbuatan mengembangkan". Artinya pengembangan disini adalah usaha untuk merubah suatu keadaan yang menjadi 
lebih baik bahkan lebih sempurna dibandingkan dengan yang sebelumnya. Dapat disimpulkan bahwa pengembangan pendidikan adalah usaha untuk meningkatkan kemampuan teksis, teoritis, konseptual dan moral sesuai dengan kebutuhan didalam kehidupan yang lebih baik dan yang lebih mengedepankan adab kemanusiaan (Nurgiansah, 2021a).

Pendidikan kewarganegaraan disinilah yang mampu menumbuhkan masyarakat Indonesia memiliki komitmen yang kuat dan konsisten yang tinggi terhadap prinsip dan semangat kebangsaan dalam berkehidupan bermasyarakat, berbangsa dan bernegara. Serta mampu menjunjung tinggi nilainilai Pancasila dan Konstitusi Negara Indonesia yang telah ditanamkan sejak dini kepada seluruh masyarakat Indonesia, khususnya generasi muda sebagai penerus bangsa. Menurut (Nadziroh:2015) Pendidikan Kewarganegaraan yang kita kenal sekarang telah mengalami perjalanan panjang dan melalui kajian kritis sejak tahun 1960-an yang dikenal dengan mata pelajaran " Civic" di Sekolah Dasar dan merupakan embrio dari " Civic Education" sebagai “ the body of knowledge". Pendidikan Kewarganegaraan sebagai " the body of knowledge" diarahkan untuk membangun masyarakat demokratis berkeadaban.

Secara normatif, Pendidikan Kewarganegaraan memperoleh dasar legalitasnya dalam pasal 3 UndangUndang No. 20 Tahun 2003 tentang Sistem Pendidikan Nasional yang mengatakan: " Pendidikan Nasional berfungsi mengembangkan kemampuan dan membentuk watak serta peradaban bangsa yang bermartabat dalam rangka mencerdaskan kehidupan bangsa".

Namun dalam pengimplementasian Pendidikan Kewarganegaraan di
Indonesia saat ini sangatlah suram, kebanyakan pendidikan yang sudah mereka pelajari sejak di usia dini tapi tidak direalisasikan dalam kehidupannya, yang terjadi bukan memberikan perubahan yang lebih baik tapi malah memberikan perubahan yang lebih buruk. Masih banyak yang tidak mengimplementasikan tujuan dari Pendidikan kewarganegaraan itu sendiri yang mengedepankan adab kemanusiaan. Seperti yang terjadi saat ini, dalam berita maupun alat informasi lainnya tentang negeri ini yang sudah sangat kehilangan nilai-nilai kemanusiaan mereka. Karena nilai-nilai keberadaban mereka telah terkubur dengan merebaknya tindakan-tindakan yang amoral seperti dalam bentuk korupsi, pemerkosaan, tawuran antarpelajar, pembunuhan, dan menyebarluaskan berita-berita hoaks tanpa diteliti terlebih dahulu kebenarannya. Maka disinilah yang harus kita bangun menjadikan masyarakat Indonesia yang demokrasi berkeadaban.

\section{METODE PENELITIAN}

Penelitian ini menggunakan studi deskriptif dengan pendekatan studi literasi. Sumber data dan instrumen pengumpulan data berasal dari artikelartikel jurnal terakreditasi. Keuntungan metode ini adalah data yang disajikan bersifat autentik, mendalam, dan natural.

\section{HASIL PENELITIAN DAN PEMBAHASAN Hasil Penelitian}

\section{A. Pengertian Demokrasi}

Secara etimologis (dikutip: buku paradigma), demokrasi berasal dari bahasa Yunani yaitu terbagi menjadi 2 kata, demos dan cratos. Demos yang berarti rakyat dan cratos yang berarti pemerintahan atau kekuasaan. Jadi secara bahasa demos-cratein atau 
demos-cratein berarti pemerintahan rakyat atau kekuasaan rakyat.

Pengertian demokrasi menurut para ahli juga tidak sama dalam mengartikan pengertian demokrasi (Menurut Hadi:2019) yaitu sebagai berikut.

1. Pengertian demokrasi menurut Abraham Lincoln adalah sebuah sistem pemerintahan yang dibentuk dari rakyat, oleh rakyat, dan untuk rakyat itu sendiri.

2. Pengertian demokrasi menurut Charles Costello adalah suatu sistem sosial dan politik yang mana kekuasaan pemerintahan dibatasi oleh hukum dan juga budaya yang melindungi segenap hak perorangan dari warga negara itu sendiri.

3. Sedangkan pengertian demokrasi menurut Hans Kelsen adalah suatu pemerintahan yang diadakan dan dilaksanakan dari rakyat dan untuk rakyat. Dan mengenai pelaksanaan kekuasaan negaranya adalah wakil dari rakyat yang sudah dipilih oleh rakyat setelah adanya keyakinan terhadap aturan yang telah ditetapkan berhubungan dengan penerapan dari kekuasaan negara.

\section{B. Maraknya Demokrasi Saat Ini}

Pada dasarnya negara Indonesia sudah sejak lama berdemokrasi, mulai dari masa order baru sampai masa orde reformasi. Namun pada beberapa kemajuan demokrasi pada decade terakhir ini kemajuan yang cukup pesat juga gelombang dahsyat yang sangat mengkhawatirkan, yaitu dengan adanya dunia maya atau biasa yang kita kenal dengan nama medsos (media sosial) yang terus menggoyang dengan berita yang tidak benar (hoaks). Pengguna medsos yang tidak bertanggung jawab dan tidak punya rasa nilai keberadaban terhadap sesama manusia, antar masyarakat, berbangsa dan bernegara.

Namun, terdapat empat prinsip yang mampu mengendalikan masalah ini apabila ke empat pilar ini dijadikan sebagai penanaman nilai tertinggi dalam hati sanubari semua masyarakat Indonesia. Empat prinsip tersebut adalah:

1. Pancasila

2. Undang-Undang Dasar Negara

Republik Indonesia Tahun 1945

3. Negara Kesatuan Republik Indonesia

4. Bhinneka Tunggal Ika

Keempat pilar ini merupakan diumpakan sebagai suatu pondasi pada sebuah bangunan yang kukuh, atau pondasi dalam hati warga negara Indonesia, yang dibangun dengan penuh perjuangan oleh para pendiri bangsa ini. Dengan harapan sebagai seorang pimpinan di lembaga kenegaraan memiliki kemampuan dan kesanggupan dalam mengatasi segala masalah yang ada di dalam negara ini.

\section{Penanaman \\ Nilai-Nilai \\ Kemanusiaan yang Adil dan Beradab}

Menurut (Hanif: 2015) Penanaman silakan ke-2 mampu diterapkan dalam bentuk berorganisasi di sekolah. Pelaksanaan penanaman nilai-nilai kemanusiaan yang adil dan beradab bisa dibentuk dalam beberapa organisasi yang sering diadakan di dalam sekolah seperti Osis, PMR, Paskibra dan Pramuka. Penanaman nilai-nilai kemanusiaan yang adil dan beradab ini bertujuan untuk mempererat tali silaturahmi, mampu menghargai orang lain, menumbuhkan sikap saling menghormati, dan terciptanya kekompakan. Beberapa macam kegiatan yang mencerminkan nilai kemanusiaan yang adil dan beradab seperti yang biasa dilakukan dalam 
organisasi yaitu bakti sosial, penanaman seribu pohon, donor darah, pelatihan rutin untuk kecakapan, dan musyawarah antar anggota.

\section{Pembahasan}

A. Membangun Masyarakat Demokrasi Berkeadaban

Demokrasi pada umumnya adalah kebebasan mengemukakan pendapat, namun demokrasi yang berkualitas adalah demokrasi yang menjunjung tinggi nilai-nilai Pancasila salah satunya tentang nilai keberadaban. "Presiden Joko Widodo sering mengatakan agar perbedaan pendapat dalam pilihan politik jangan sampai membuat kita terpecah-belah. Jangan kita bermusuhan hanya karena proses sesaat di kotakkotak suara. Karena itu, kita perlu membangun demokrasi yang berkualitas" ujar V. Hargo Mandirahardjo, SH. M.Kn. Artinya sifat dari demokrasi disini adalah memiliki esensi yang menjunjung tinggi nilai keberadaban juga nilai kesopanan dan santun, maka sangatlah penting kita menyikapi permasalahan tentang berita yang belum tentu kebenarannya, yang pastinya memastikan terlebih dahulu bukti dari isu-isu tersebut, jangan sampai menimbulkan perpecahan antar masyarakat, berbangsa maupun bernegara. Dalam ayat suci Al-Quran pun dijelaskan bahwa kita harus mau meneliti kebenaran atau berita yang sampai kepada kita atau berita yang sedang viral di sosial media, yang berbunyi "Hai orang-orang yang beriman, jika datang kepadamu orang fasik membawa suatu berita, maka periksalah dengan teliti agar kamu tidak menimpakan suatu musibah kepada suatu kaum tanpa mengetahui keadaannya yang menyebabkan kamu menyesal atas perbuatanmu itu". (AlĤjurāt: 6)
Dalam Pembukaan Undang-Undang Dasar 1945 di dalam alinea yang ke 3 berbunyi "Mencerdaskan Kehidupan Bangsa". Ini merupakan tanggung jawab negara dalam mewujudkannya dan merupakan kewajiban masyarakat Indonesia untuk menjadi warga negara yang cerdas. Menurut Prof. Dr. Asep Warlan Yusuf. SH.,MH. Seorang dosen Fakultas Hukum Unpar Bandung dalam orasi yang beliau buat terdapat pernyataan seorang jurnalis dan pengarang tenama di Indonesia yaitu Mochtar Lubis pernah menyebutkan dalam bukunya yang berjudul " Manusia Indonesia" bahwa ciri atau steriotip manusia Indonesia itu ialah: 1. Munafik; 2. Enggan atau segan untuk bertanggung jawab atas perbuatannya; 3. Bersikap dan berprilaku feodal; 4. Percaya takhayul; 5. Artisitik berbakat seni; 6 . Lemah watak atau karakter. Ciri tersebut tentu ada benarnya dan juga banyak salahnya.

Yang dimaksud bangsa yang cerdas menurut UUD 1945 tidak hanya sekedar bangsa yang pintar, berwawasan luas, atau berpengetahuan, tetapi jauh lebih mendasar dari itu yaitu bahwa kehidupan bangsa yang cerdas itu meliputi:

1. Berketuhanan, artinya bangsa yang senantiasa taat dalam menjalankan ajaran dan perintah Agama dan menjauhi segala larangan-Nya dengan konsisten, baik, dan benar.

2. Berperikemanusiaan, artinya bahwa watak atau karakter bangsa Indonesia adalah hidup dan kehidupan itu harus dijalani dengan merdeka, tidak boleh ada satu pun yang menghalangi, mengganggu, dan mengurangi kemerdekaan bangsa Indonesia. Dalam arti cerdas disini adalah cerdas anti penjajahan, maka dari itu kita butuh pemimpin yang tegas dan 
berani mengatakan "Tidak" kepada penjajah.

3. Berbudi Pekerti Luhur, artinya Membangun dan menjalankan Negara untuk mencapai masyarakat yang tata tenteram kertaraharja harus berlandaskan moral dan budi pekerti yang luhur yang harus dimiliki khususnya oleh penyelenggara negara.

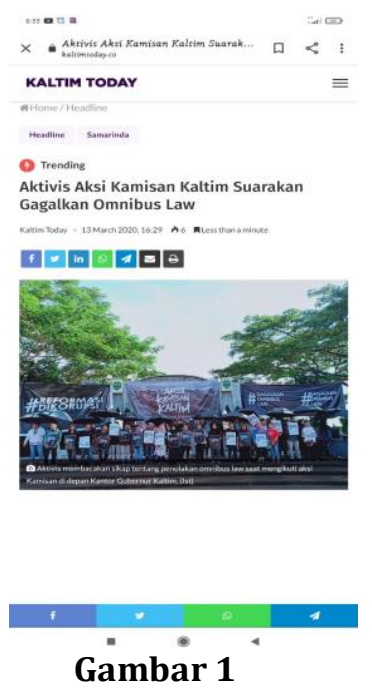

Cerminan karakter bangsa yang berbudi pekerti luhur untuk saat ini adalah membangun masyarakat demokrasi yang berkeadaban. Karena maraknya permusuhan antar sesama, antar masyarakat, berbangsa maupun bernegara, lalu saling membully, saling mencemoohkan di dalam sosial media, sehingga masyarakat lupa akan hal keberadaban. Dan menyalahartikan definisi dari demokrasi tersendiri. Maka dari itu patutlah kita menjadi warga negara yang cerdas, mampu menggunakan akal budinya dengan baik. Semua manusia memahami mana yang benar dan mana yang salah, jika akal budi kita digunakan untuk hal yang baik maka terjalinlah kebersamaan antar masyarakat atau timbulnya rasa keharmonisan dan ketenteraman dalam suatu negara (Nurgiansah, 2020a).
B. Krisisnya Demokrasi di Indonesia Namun yang jadi masalahnya adalah ketika masyarakat mengadukan permasalahannya, mendemokrasi tentang keadilan di negaranya. Negara mengabaikan bahkan pemerintahnya malah memberikan sanksi terhadap orang yang berani mengemukakan pendapat tentang kebenaran yang terjadi pada negaranya.

Seperti yang terjadi di Kalimantan Timur, kamis (12/3/2020) para aktivis dan buruh menggelar aksi kamisan, dalam menyampaikan penolakan terhadap Omnibus Law yang diberi julukan anti Demokrasi. Mereka menganggap bahwa Presiden Joko Widodo dan Omnibus Law ini telah berbuat yang serempangan, yang menciptakan pengabaian partisipasi dan tanggapan dari masyarakat atau publik.

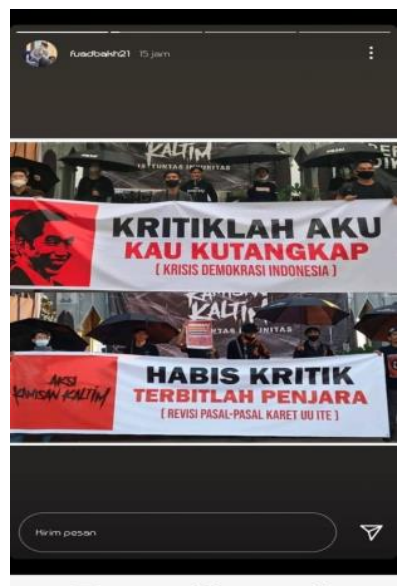

Gambar 2

Dalam aksi tersebut, beberapa orasi dilakukan kalangan mahasiswa dari Fakultas Hukum, Fisipol. Massa juga sempat lakukan simbolis aksi dengan menenteng poster bertuliskan "Gagalkan Omnibus Law" , "Kritiklah Aku, Kau Kutangkap", dan " Habis Kritik, Terbitlah Penjara". Miris sekali negara ini dengan melihat aksi dari para mahasiswa Kalimantan Timur, negara yang enggan tegaknya kebenaran, yang enggan memberikan keadilan kepada 
masyarakat Indonesia. Yang sering mengalami tindasan, kekejaman dari para atasan yang memiliki kekuasaan tertinggi di negara.

Itulah pentingnya manusia itu cerdas, betul sekali apa yang disebutkan dalam UUD 1945 bahwa cerdas itu tidak hanya orang itu pintar, berwawasan luas, ataupun berpengetahuan tinggi. Namun cerdas itu harus mampu menggunakal akal budinya dengan benar yaitu mampu membedakan mana yang benar dan mana yang salah, dan mampu memposisikan dirinya pada jalan yang benar sekalipun pahit. Menegakkan kebenaran tidaklah manis, semua butuh perjuangan serta perlu orang-orang yang berani, karena kebanyakan di negara ini takut dan tidak suka bila masyarakat Indonesia semangat dalam menegakkan kebenaran (Nurgiansah, 2020b).

Menurut pernyataan dari Anggota Panja Rancangan Kitab Undang-Undang Hukum Pidana (RKUHP), Teuku Taufiqulhadi, menilai bahwa pasal yang mengatur penghinaan terhadap kepala negara tidak akan dipermasalahkan di kemudian hari. Beliau menjelaskan bahwa ada perbedaan dalam mengkritik dan menghina, menurutnya "Kalau mengkritik, itu tidak personal. Namun, kalau menghina, itu personal dan tidak ada hubungan apa pun dengan seseorang sebagai kepala negara," kata Taufiqulhadi. Jadi pasal yang menyatakan pengkritikan terhadap kepala negara tidak akan dipermasalahkan, karena pasal tersebut telat dibuat secara delik aduan, artinya delik aduan yang absolut mutlak tidak akan dipermasalahkan.

Pakar hukum pidana Universitas Al Alzhar, Suparji Ahmad, mendukung pengesahan RKUHP. Suparji menilai sejumlah aturan baru dalam RKUHP lebih baik ketimbang KUHP warisan Belanda. Beliau memberikan pernyataan dukungan terhadap pasa tersebut bahwa "Materi pasal sudah melalui semacam batu uji yang berpedoman pada Pancasila, konstitusi, nilai-nilai budaya, dan hukum-hukum yang berlaku di dunia yang beradab. Jadi materinya relatif lebih baik," kata Suparji.

Anggota Dewan Pers Agung Darmajaya meminta RKUHP jangan sampai tumpang-tindih dengan UU Nomor 40 Tahun 1999 tentang Pers. "Ketika muncul persoalan pers, masuk ke KUHP menjadi pidana. Artinya, kebebasan pers di satu sisi terbelenggu pidana, akhirnya jadi tumpang-tindih," kata Agung, akhir pekan lalu. Akhirnya di mengingatkan bahwa ketika terjadi persoalan dalam sebuah pemberitaan, itu harus diselesaikan dengan UU Pers, bukan pidana.

\section{Alasan Pentingnya Mempelajari Pendidikan Kewarganegaraan Menurut \\ (Sunarso:2006)}

Pendidikan di Indonesia memiliki peranan dan tanggung jawab yang sangat penting dalam membina warga negara agar memiliki komitmen yang kuat dan konsisten terhadap Negara Kesatuan Republik Indonesia. Upaya yang dapat dilakukan adalah menyelenggarakan program pendidikan yang memberikan berbagai kemampuan sebagai seorang warga negara melalui mata pelajaran Pendidikan Kewarganegaraan (citizenship).

Pendidikan kewarganegaraan merupakan program pendidikan yang memfokuskan pada pembentukan diri yang beragam dari segi agama, sosialkultural, bahasa, usia, dan suku bangsa untuk menjadi warga negara Indonesia yang cerdas, terampil, dan berkarakter yang dilandasi oleh Pancasila dan UUD 1945. (Pusat Kurikulum Balitbang Depdiknas, 2002 : Sunarso, 2006).

Mengapa terus selalu dikaitkan 
dengan Pancasila?. Sebab Pancasila merupakan Ideologis bangsa Indonesia. Secara etimologi Pancasila terdiri dari dua kata yaitu "Panca" yang berarti lima dan "Sila" yang berarti aturan yang melatarbelakangi perilaku seseorang atau bangsa yang dijadikan sebagai dasar dalam beradab. Menurut (Sulistyani:2019) bahwa kelima sila tersebut berperan menjadi pandangan hidup, keyakinan, atau cita-cita bangsa Indonesia yang berfungi sebagai dasar dalam mengambil suatu keputusan terhadap berbagai persoalan yang dihadapi bangsa Indonesia.

Namun terdapat masalah dalam penerapan nilai-nilai Pancasila yang mulai luntur di Indonesia. Dalam makna seorang manusia adalah makhluk Tuhan yang sempurna dan otonom terdiri dari jasmani dan rohani, mempunyai sifat sebagai individu dan makhluk sosial. Dalam bahasa Jawa terdapat istilah yang menunjukkan sifat kodratnya manusia yaitu bahwa manusia tidaklah sempurna karena memiliki karakter seperti apes, lali, murka, dan rusak.

Menurut (Hasnah, dkk: 2019) peristiwa yang terjadi penyebab luntuh nilai- nilai Pancasila yaitu adanya seorang terorisme yang menggunakan bom bunuh diri untuk melukai, bahkan membunuh orang-orang yang menjadi sasaran mereka. Padahal di dalam agama tidak mengajarkan hal itu apabila itu terjadi Allah SWT yang akan melaknatnya, apabila kita membunuh tanpa sebab dan akibat yang kuat. Namun apabila membunuh dan orang yang dibunuh itu berbahaya bagi orang lain atau telah melakukan dosa yang besar maka hukumannya bisa saja pembunuhan (Nurgiansah, 2019).

$$
\text { Melalui }
$$

pendidikan

kewarganegaraan ini diharapkan warga negara mampu memahami, menganalisis, serta menyelesaikan masalah yang dihadapi masyarakat, berbangsa maupun bernegara secara tepat, rasional, konsisten, dan bertanggung jawab dalam rangka mencapai tujuan nasional. Menjadi warga negara yang mengetahui atas hak dan kewajibannya, menguasai ilmu dan teknologinya, namun tak lupa dengan jati dirinya (Dewantara, Hermawan, et al., 2021).

\section{Butir-butir Nilai Pancasila Sila} Kedua Menurut Tafsir Mudhu'iyah

Butir nilai pertama dari Sila kedua Pncasila: "Mengakui dan memperlakukan manusia sesuai dengan harkat dan martabatnya sebagai makhluk Tuhan Yang Maha Esa" relevan dengan: QS alMâidah ayat 8. Menurut al-Maraghi bahwa ayat ini memerintahkan manusia untuk berlaku adil dalam berbagai situasi termasuk menjadi saksi.

Butir nilai kedua dari sila kedua pancasila: "Mengakui persamaan derajad, persamaan hak dan kewajiban asasi setiap manusia, tanpa membeda bedakan suku, keturunan, agama, kepercayaan, jenis kelamin, kedudukan sosial, warna kulit dan sebagainya" relevan dengan: QS. al-Hujarat 13. Ayat ini menerangkan bahwa manusia itu adalah sama dihadapan Allah, tiada suatu bangsa mempunyai kekebihan dengan yang lain, semuanya adalah sama-sama anak cucu Adam yan membedakan mereka adalah tingkat ketaqwaan saja.

Butir nilai ketiga dari Sila kedua Pancasila: "Mengembangkan sikap saling mencintai sesama manusia" relevan dengan: QS. al-Mumtahanah 7:ayat menerangkan bahwa boleh jadi yang selama ini menjalin permusuhan diubah oleh Allah menjadi saling mencintai dan menjadi sahabat yang baik.

Butir nilai keempat dari Sila kedua: "Mengembangkan sikap saling tenggang 
rasa dan tepa selira relevan" dengan QS.al-Maidah 2. ayat ini ditafsikan sebagai ayat perintah bertolong-tolongan dalam mengerjakan kabaikan dan takwa, adalah termasuk pokok-pokok petunjuk sosial dalam alQuran (Dewantara, Nurgiansah, et al., 2021).

Butir nilai kelima dari Sila kedua Pancasila: "Mengembangkan sikap tidak semena-mena terhadap orang lain relevan" dengan: QS.al-Maidah 8. Ayat ini memerintahkan kepada setiap mukmin menegakkan kebenaran dengan penuh keikhlasan baik urusan agama maupun dunia. Sehingga inti dari melaksanakan perintah tersebut adalah kebenaran.

Butir nilai keenam dari Sila Kedua Pancasila: "Menjunjung tinggi nilai-nilai kemanusiaan" relevan dengan: QS.al-Isra' 70: Allah swt dalam firman-Nya ini mengingatkan umat manusia akan kedudukan mereka yang dilebihkan atas makhluk Allah yang lainnya (Nurgiansah, 2021b).

Butir nilai ketujuh dari Sila kedua Pancasila: "Gemar melakukan kegiatan kemanusiaan" relevan dengan QS.al-Isra' 26. Tentu yang dimaksud pemberian disini tidak hanya materi, namun dapat juga hal-hal yang immateri (Dewantara \& Nurgiansah, 2021).

Butir nilai kedelapan dari Sila kedua Pancasila: "Berani membela kebenaran dan keadilan" relevan dengan : QS. an-Nisa' 58 Allah mewajibkan setiap orang berlaku adil dalam kedudukan apapun, baik sebagai pemimpin terhadap rakyat, ulama terhadap masyarakat biasa dan seterusnya.

Butir nilai kesembilan dari Sila kedua Pancasil: "Bangsa Indonesia merasa dirinya sebagai bagian dari seluruh umat manusia" relevan dengan: QS.al- Baqarah 213. Allah telah memastikan bahwa umat manusia bagaikan umat yang satu, di mana antara satu dengan lainnya saling behubungan.

Butir nilai kesepuluh dari Sila kedua Pancasila: "Mengembangkan sikap hormat menghormati dan bekerjasama dengan bangsa lain" relevan dengan QS.al-Hujarat 11. Ayat di atas memberi petunjuk agar tidak terjadi pertikaian, salah satunya dilarang mengolok-olok, sebaliknya menghormati (Nurgiansah, 2021c).

\section{E. Implementasi Demokrasi di Masyarakat \\ Menurut (Arif : 2013) menjelaskan} bahwa suatu ide dan konsep akan menjadi utuh ketika diimplementasikan dalam kehidupan sehari-hari. Dalam prkatik demokrasi pada saat itu sangat beragam dilihat dari situasi dan kondisinya. Sehingga dengan demokrasi yang sangat beragam di kalangan masyarakat maka dalam perwujudannya pun memiliki keragaman yang banyak. Dan diklasifikasikan ke dalam beberapa suatu konsep.

Pertama, memahami praktik demokrasi sebagai sikap dan perilaku dalam kehidupan sosial dan politik. Kedua, memahami penerapan demokrasi sebagai kegiatan partisipasi dalam kegiatan sosial poltik. Ketiga, memahami pelaksanaan demokrasi sebagai mematuhi aturan atau mendukung kebijakan pemerintah.

Dengan berubahnya menjadi orde reformasi, memberikan berbagai pengaruh penting terkait perubahan pemahaman dan kesadaraan politik masyarakat berupa menyebarnya ide tentang kesetaraan, kebebasan dalam berpendapat atau aspirasi menjadi ide utama dalam. Dan di sisi lain demokrasi yang dimaknai sebagai kebebasan juga memberikan dampak perubahan yang cukup berarti. Saat ini penyerobotan terhadap hak public, pengabaian 
keberadaan negara, intoleransi terhadap perbedaan dan hak orang lain kerap terjadi. Masyarakat bebas melakukan apapun yang diinginkan dengan dalih kebebasan di era demokrasi. Kondisi ini berlangsung di berbagai tempat sehingga menghasilkan perubahan tatanan yang tidak lagi terarah di masyarakat.

Menurut (Hartuti:2004) dalam memasuki iklim demokrasi yang baik dan benar adalah perlunya pendewasaan. Sebab untuk mendirikan (sistem) demokrasi bukan hanya perlu kebebasan yang berserikat saja. Bukan hanya kualitas pers yang bebas, tetapi juga kualitas ketanggapan pembacanya. Bukan hanya kebebasan mimbar atau kebebasan berbicara semata, tapi juga kedewasaan pembicaraannya. Dan bukan hanya menuntut kualitas legislatif yang bisa menyuarakan hati nurani rakyat saja, tetapi juga menuntut kualitas eksekutif agar bisa menangkap suara hati nurani rakyat. Tanpa pemahaman dan kedewasaan, demokrasi akan berubah menjadi demo-crazy dan hanya akan membingungkan rakyat sebagaimana dilukiskan Pudjo Suharso dalam sajaknya seperti yang dibawah ini. "Aku mau kamu mau dia mau, yang kita mau terjadi, tapi yang terjadi tak diinginkan, oleh satu pun diantara kita" (Pudjo Suharso,2002).

Adapun ayat yang relevan dengan permasalahan demokrasi yang tidak berkeadaban, QS (Al-Ĥujurāt):6 - Hai orang-orang yang beriman, jika datang kepadamu orang fasik membawa suatu berita, maka periksalah dengan teliti agar kamu tidak menimpakan suatu musibah kepada suatu kaum tanpa mengetahui keadaannya yang menyebabkan kamu menyesal atas perbuatanmu itu.

\section{KESIMPULAN}

Harapan bangsa Indonesia adalah kita mampu menjalin keharmonisan dan ketenteraman di dalam masyarakat, berbangsa dan bernegara. Dengan cara menjunjung tinggi nilai-nilai Pancasila yaitu salah satunya nilai keberadaban. Pendidikan Kewarganegaraan memiliki tujuan agar masyarakat Indonesia memiliki komitmen yang tinggi dan konsisten terhadap nilai Pancasila dan prinsip Konstitusi Negara Indonesia. Menjadikan warga negara yang cerdas, sehingga mampu menghilangkan kebiasaan buruk dan memiliki karakter yang berbudi pekerti luhur. Sehingga mampu menjadikan warga negara demokrasi yang berkadaban di dalam lingkungan sekitar.

Saya ucapkan terimakasih banyak kepada Ibu Dinie Anggreani. S. Pd. selalu dosen pengampu mata kuliah Konsep Dasar Pendidikan Kewarganegaraan yang telah membimbing saya dalam pembuatan artikel ini. Dan ucapan terimakasih banyak kepada pembaca dan saya harap terdapat pemberian kritik dan sarannya untuk penyempurnaan artikel yang saya buat ini.

\section{DAFTAR PUSTAKA}

Daheri, M, dkk. 2020. Butir-Butir Pancasila Dalam Kajian Tafsir Mudhu'iy. FOKUS : Jurnal Kajian Keislaman dan Kemasyarakatan Vol. 5, No. 2, 2020

Dewantara, J. A., Hermawan, Y., Yunus, D., Prasetiyo, W. H., Efriani, Arifiyanti, F., \& Nurgiansah, T. H. (2021). Anti-Corruption Education as an Effort to Form Students With Character Humanist and Law-Compliant. Jurnal Civics: Media Kajian Kewarganegaraan, 18(1), 7081.

Dewantara, J. A., \& Nurgiansah, T. H. (2021). Building Tolerance Attitudes Of PPKN Students Through Multicultural Education Courses. Jurnal Etika Demokrasi, 6(1), 103-115. 
Dewantara, J. A., Nurgiansah, T. H., \& Rachman, F. (2021). Mengatasi Pelanggaran Hak Asasi Manusia dengan Model Sekolah Ramah HAM (SR-HAM). Edukatif: Jurnal Ilmu Pendidikan, 3(2), 261-269.

Herlambang, T, Y. 2018. PEDAGOGIK: Analisis Fenomena Pendidikan Indonesia. Jakarta:Bumi Aksara.

Humas Kemenko Polhukam RI. 2020. Tujuan Negara Mencerdaskan Kehidupan Bangsa Bukan Otak Manusia Saja. Jakarta:KemenkoPolhukam

Kartono, H. 2019. MEMBAGUN DEMOKRASI BERKEADABAN DAN DINAMIKA PEMILIHAN PRESIDEN LANGSUNG 2019. Jurnal HUKUM DAN DINAMIKA MASYARAKAT VOL.16 NO.2, hal 132.

Lestari, E, S. 2019. KAJIAN ISLAM TERHADAP SILA KEDUA DALAM PANCASILA SEBAGAI PENJAGA MULTIKULTURALISME. Jurnal Pendidikan Multikultural, Volume 3 Nomor 2, Agustus 2019.

Nadziroh. 2015. Membangun Masyarakat Demokratis Melalui Pendidikan Kewarganegaraan. Trirahayu : Jurnal Pendidikan Ke-SD-an, vol 2, Nomor 1, hlm. 263-266.

Nurgiansah, T. H. (2019). Pemutakhiran Kurikulum Pendidikan Kewarganegaraan di Era Revolusi Industri 4.0. Prosiding Seminar Kewarganegaraan Universitas Negeri Medan, 1(1), 95-102.

Nurgiansah, T. H. (2020a). Fenomena Prostitusi Online Di Kota Yogyakarta Dalam Persfektif Nilai Kemanusiaan Yang Adil Dan Beradab. Jurnal Kewarganegaraan, 17(1), 27-34. https://doi.org/10.24114/jk.v17i1.14208

Nurgiansah, T. H. (2020b). Filsafat Pendidikan. In Banyumas: CV Pena Persada.

Nurgiansah, T. H. (2021a). Pendidikan Pancasila. In Solok: CV Mitra Cendekia Media.

Nurgiansah, T. H. (2021b). Petuah Pendidikan Kewarganegaraan Dalam Kontestasi Politik. AoEJ: Academy of Education Journal, 12(1), 39-47.

Nurgiansah, T. H. (2021c). The Role of Citizenship Education in Building Bantul Community Political Participation in The Pandemic Covid 19. Prosiding Seminar Nasional Pendidikan Dan Kewirausahaan, 4(1), 1-4.

Nurjanah, H. 2015. Penanaman Nilai-Nilai Sila Kemanusiaan yang Adil dan Beradab Dalam Kegiatan Berorganisasi Di Sekolah. Surakarta, Artikel Publikasi.

Purnaweni, H. (2004). Demokrasi Indonesia : Dari Masa ke Masa. Jurnal Administrasi Publik Vol 3 No. 2, UNPAR, 2004.

Siregar, H, dkk. 2019. Hilangnya Nilai Pancasila. FAKULTAS TARBIYAH DAN ILMU KEGURUAN INSTITUT AGAMA ISLAM NEGERI (IAIN) PADANG SIDIMPUAN.

Sofyan, A. 2013. Pemaknaan Demokrasi di Era Reformasi. Jurnal Politika, Vol. 4, No. 2, hal 8-11.

Sunarso. 2006. Membangun Masyarakat Demokratis Yang Bermoral Lewat Pendidikan Kewarganegaraan. Jurnal Civics, Vol 3, No. 1, Juni 2006.

Winarno. 2020. Paradigma Baru Pendidikan Kewarganegaraan. Jakarta:Bumi Aksara.

Yusuf, W, A. 2016. Tanggung Jawab Negara Dalam Mencerdaskan Kehidupan Bangsa. Fakultas Hukum Unpar Bandung. 